\title{
In Memoriam: Dr. Robert George Lee (July 2, 1936-March 31, 2017)
}

\author{
Werner J. Becker
}

doi:10.1017/cjn.2017.231

Can J Neurol Sci. 2017; 44: 761-762

On March 31, 2017, Robert (Bob) Lee collapsed suddenly on Nose Hill in Calgary while hiking with a friend. Although he was 80 years old, he was still vigorous and apparently in good health. His sudden death caught all of usfamily, friends, and colleagues - by surprise. Now, after our initial shock and sorrow, is the time to reflect on this remarkable man who touched so many lives, who was an inspiration to so many of us.

Bob had a long and unusual medical career. After completing his rotating internship at the Toronto General Hospital in 1961, he worked as a family physician in Terrace Bay in Northern Ontario for two years. This was followed by neurology residency training in Toronto and two years of neurophysiology fellowship training at the Mayo Clinic in Rochester, Minnesota. He returned to Toronto in 1968 and worked for five years as a neurologist at the Toronto Western Hospital. Interestingly, during this time he also did three onemonth locums as a family physician in locations ranging from northern Newfoundland on the east coast to Haida Gwaii on the west coast. In 1974, he began a long and successful career in Calgary that lasted until he retired from clinical practice in 2005.

When Bob first arrived in Calgary, he quickly demonstrated his flexibility, his forward-looking nature, and his ability to work with many different people and groups to get things done. He came into a system that was dominated by clinicians but was able to assess the strengths and weaknesses of the situation and move forward with a plan to develop neurology and neuroscience in Calgary, including education and research. He quickly established an excellent electromyography laboratory and was highly respected as a teacher. Bob was able to form strong relationships with the education and research groups at the young University of Calgary Medical School, and he showed his flexibility by embracing the new Calgary problem-based curriculum even though he himself had just come from a much more traditional medical school at the University of Toronto. He worked with Frank LeBlanc and many others to develop the clinical neurosciences in Calgary, arriving in time for the installation at the Foothills Hospital of the first CT scanner (EMI Group Ltd., London) in Western Canada.
One of his major accomplishments in Calgary. in association with Frank LeBlanc, Peter Seland, and Michael Hunter, was the formation of a Department of Clinical Neurosciences in 1981 that combined neurology, neurosurgery, and later physiatry. Bob Lee became the first head of this new department, and under his leadership (which lasted until 1991), the department experienced strong academic and clinical growth. He also chaired the Neuroscience Curriculum Subcommittee, the Neuroscience Research Group, and the Faculty of Medicine Admissions Committee. On a national level, he al College Examination Board in Neurology, president of the Canadian Neurological Society, and as executive vice-president of the Canadian Congress of Neurological Sciences (CCNS). Among the many great contributions that Bob made to the clinical neurosciences in Canada were the negotiations that he spearheaded with the founder of the Canadian Journal of Neurological Sciences (CJNS), Dr. Bob Ross, which eventually led to the transfer of the CJNS to the CCNS. When the transfer was finalized, Bob believed his job to be finished, but he later recounted how, in 1981, immediately after the transfer, Charles Tator, chair of the publications committee, literally pinned him to the wall in a corridor of the Chateau Laurier, and would not release him until he agreed to become editor-in-chief. He held this position with distinction for 10 years.

As time went on, Bob became more and more interested in fostering medical education in developing countries. From 1982 onwards, he participated in programs in Nepal, China, the Philippines, Malaysia, Laos, and Tajikistan. With his wife Pat accompanying him on many of his journeys, he traveled to the most remote, poor, and risky regions of many of these countries in

From the Department of Clinical Neurosciences, University of Calgary, Calgary, Alberta, Canada.

Received June 5, 2017. Date of Acceptance June 7, 2017.

Correspondence to: Werner J. Becker, Room 1007D, Health Sciences Centre, 3330 Hospital Drive NW, Calgary, Alberta, Canada T2N 4N1. Email: wbecker@ucalgary.ca 
order to plan or support medical training for doctors so that they would become more effective in serving the most disadvantaged regions. They met with local families, health professionals, and administrators-showing respect and interest in local life and practices. This capacity that Bob had to be able to move from Western comforts to live among those in abject poverty is a rare characteristic, and it built understanding, trust, and effectiveness. He identified several promising young professionals in developing countries, and then personally supported them to access advanced neurological training abroad and to return to fill major manpower needs in their home institutions.

In Laos, Bob worked with Clarence Guenter, and spent considerable time there, including in remote rural areas. He left good records of some of his experiences in the Laos Family Medicine Specialty Program Community Project. This project placed interns in remote rural villages, and Bob visited many of these with his wife Pat. This involved traveling more than $2,600 \mathrm{~km}$, much of it over rough dirt roads. Bob's account of this experience provides many insights into life in rural Laos at that time. He reported that when he visited one village a patient arrived to see the interns with a severely crushed and lacerated hand from a logging accident. After the wound was cleaned and dressed, the interns sought to send him to the district hospital to have the hand sutured. The man refused to go because he could not afford to pay for fuel for a tractor to get him there, let alone pay the hospital fees. Bob intervened and paid for both. In another village, the four interns could do little work after dark because their compound had no electricity. Bob paid for a 12-volt battery, which they could charge every few days at a generator in the village.

Traveling in these areas was not always easy, and in one case, after arriving in a village after dark, Bob and Pat stayed in the only available accommodation-a small 8-by-8 foot room with no window and no fan, but lots of bugs. His reports provided poignant commentary on the public health needs of rural Laos. In one village, the source of the water supply was a pond covered with green scum, which had a water buffalo wallowing nearby. In another village, a survey done by the interns revealed that only $15 \%$ of homes had a toilet of any type. Bob was a man who was wise enough to help when he could, was willing to show respect to all those he came in contact with, and, despite the difficulties he encountered, was able to enjoy himself most of the time. Many physicians might envy the impact that the interns in the program he supported in Laos had on the local population. Bob reported that in one local restaurant the cook volunteered, "Before there was a lot of sickness in this village-now that we have good doctors, the bad diseases are afraid to come!"

Bob was energetic and multifaceted. He served as team physician for expeditions to Mount Orizaba in Mexico and Mount Aconcagua in Argentina, and he personally climbed to the summit of both. In 1986, he spent three months in Tibet as team physician for a Canadian expedition that reached the summit of Everest, and during this expedition he carried out research on the neuropsychological effects of prolonged exposure to high altitude. Bob loved the Canadian Rockies and had his happiest times at his cabin in Kananaskis Country west of Calgary. He was an avid hiker and skier.
Although dedicated and hardworking, Bob was also noted for his sense of humor. In 1980, Frank LeBlanc and Bob created quite a sensation when they appeared at a social function at the Canadian Congress of Neurological Sciences in Ottawa in full Arabian regalia as two "blue-eyed sheiks." This was the time of the unpopular (in Alberta) National Energy Policy of Canada, and this unexpected and dramatic appearance of an Alberta neurologist and a neurosurgeon in full Middle-Eastern dress brought a smile to the faces of many of us. It's certainly an image I'll never forget.

On a personal note, one of my first meetings with Bob occurred when I arrived in Calgary as a young neurologist in 1978, as he was at that time neurology division director. He was also chief examiner for neurology when I took my Royal College oral examinations in November of 1978. As I had just moved to Calgary, he took only a minor part in my orals to avoid any conflict of interest. Bob ran a significant research laboratory that focused on control of movement, with 22 consecutive years of research funding, mainly from the Medical Research Council of Canada. After I had been in Calgary for some years, he invited me to join him in his laboratory, and we published our first research paper together in 1987. Here I was able to rub shoulders with masters and doctoral students, as well as several fellows who came from Japan to work with him.

Throughout my work with him in the lab and in the division of neurology, he was always what could be best described as even-handed and supportive, characteristics that no doubt were major contributors to his success as a leader in so many areas. As his good friend Albert Aguayo put it, Bob touched and was admired by so many for all that he accomplished throughout his life because he often did it in ways that most of us were not able to or did not dare to do.

Indeed, Bob shared his energy and his talents generously. After retiring from clinical practice in 2005 , he became increasingly committed to environmental protection. He worked with the Nature Conservancy of Canada and used his skills as a photographer to increase public awareness of environmentally sensitive areas. He also served as board chairman for several local environmental organizations.

In short, Bob was a man who contributed greatly to society in many different areas. He was dear to many of us, not just because of his accomplishments, but because he was a warm and generous man who was respectful to all-a man who helped many others to achieve their fullest potential.

\section{Disclosures}

Dr. Becker reports grants and personal fees from Allergan and Amgen, and personal fees from Tribute, Serono, Teva, and Electrocore. He was also a longtime colleague of Dr. Lee in the Department of Clinical Neurosciences at the University of Calgary.

Werner J. Becker

Department of Clinical Neurosciences University of Calgary, Calgary, $A B$ 